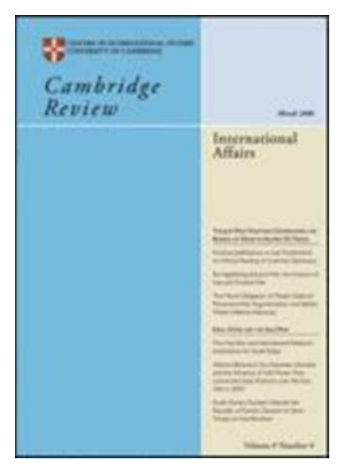

\title{
Uneven and Combined Confusion: On the Geopolitical Origins of Capitalism
}

\begin{tabular}{|r|l|}
\hline Journal: & Cambridge Review of International Affairs \\
\hline Manuscript ID & Draft \\
\hline Manuscript Type: & Original Article \\
\hline Keywords: & $\begin{array}{l}\text { international political economy, transition to capitalism, carbon capitalism, } \\
\text { captialization, capital as power }\end{array}$ \\
\hline
\end{tabular}

\section{SCHOLARONE \\ Manuscripts}

URL: http:/mc.manuscriptcentral.com/gieh Email: criacis@hermes.cam.ac.uk 


\section{Uneven and Combined Confusion:}

On the Geopolitical Origins of Capitalism and the Rise of the West 


\section{Abstract:}

This article offers a critique of Alexander Anievas and Kerem Nişancioğlu's How the West Came to Rule: The Geopolitical Origins of Capitalism. We argue that while all historiography features a number of silences, shortcomings or omissions, the omissions in How the West Came to Rule lead to a mistaken view of the emergence of capitalism. There are two main issues to be confronted. First, we argue that Anievas and Nişancioğlu have an inadequate and misleading understanding of 'capital' and 'capitalism' that tilts them towards a theoretical stance that comes very close to arguing that everything caused capitalism while at the same time having no clear and convincing definition of 'capital' or 'capitalism'. Second, there are at least three omissions particular to England/Britain within a geopolitical context - that should be discussed in any attempt to explain the development of capitalism: the financial revolution and the Bank of England, the transition to coal energy and the capitalization of state power as it relates to war, colonialism and slavery. We conclude by calling for a connected histories approach within the framework of capital as power. 
There is little doubt that 'any historical narrative is a particular bundle of silences.' (Trouillot 1995: 27). These silences are unavoidable in any historiography, not least ones that attempt to account for the emergence of capitalism and the rise of the so-called 'West'. Such accounts have been perennial in IR/IPE and much is at stake in the present for how we understand and assess these accounts (Anievas and Nişancioğlu 2013, 2015; Beaud 2001; Bhambra 2010; Braudel 1983; Brenner 1976, 1977, 1978; Byers 1996; Dimmock 2014; Dobb 1946/1963; Harman 2004, 2006, 2008; Heller 1985, 2011; Hilton 1976a, 1976b, 1976c; Hobson 2004; McNally 1988; Mielants 2007; Nitzan and Bichler 2009; Sweezy 1954; Tawney 1926; Wallerstein 1974; Wood 2002; Zmolek 2013). This is particularly true for Marxists who generally think of capitalism as having hard-wired internal contradictions that will ultimately lead to its self-destruction and the dawn of communism. The aim of this article is to offer a foundational critique of one of the most recent and in many ways masterful Marxist accounts of the transition to capitalism and the 'rise of the West': How the West Came to Rule: The Geopolitical Origins of Capitalism by Alexander Anievas and Kerem Nişancioğlu (2015). Our main argument is that while 'silences' are inevitable in all historical accounts - including our own - the silences in How the West Came to Rule contribute to a mistaken view of the emergence of capitalism and the so-called rise of 'Western' power. As we see it, there are at least two main problems. First, we argue that Anievas and Nişancioğlu have an inadequate and misleading understanding of 'capital' and 'capitalism' that tilts them towards a theoretical stance that comes very close to arguing that everything caused capitalism while at the same time having no clear and convincing definition of 'capital' or 'capitalism'. In their analysis there is also the liberal tendency to see capitalism as inevitable: history had to arrive at capitalism and the logic of accumulation - the only difference being some got there first. Second, we argue that whatever the merits of their account - and at least in our judgment, they are considerable in many respects - there are crucial historical events that contribute to the emergence of capitalism that are completely overlooked, significantly weakening their overall argument. To unpack our arguments, we have organized this article in the following way. First, we provide a brief summary of the main argument in How the West Came to Rule. With this in background, in part two we move to critically evaluate Anievas and Nişancioğlu's understanding of 'capital' and 'capitalism' from the Capital as Power perspective in critical IPE. As readers will be able to tell, we find their analytical definition conceptually fuzzy and ultimately unconvincing. This sets the stage for the third part of our article where we 
discuss three major omissions that are we argue are critical for a convincing explanation for the inter-societal or geopolitical emergence of global capitalism. Briefly, these silences include the financial revolution and the creation of the Bank of England, the transition to coal energy, and last, the capitalization of the state as it relates to international warfare, colonialism and Atlantic slavery. In the final section, we propose how debates might be able to move forward if we combine a connected histories approach with the Capital as Power perspective. In this way, we will not only have a convincing definition of capital and capitalism but also an understanding of the international interconnections that geopolitically constituted and continue to constitute capitalism.

\title{
How the West Came To Rule Key Arguments
}

At base, Alexander Anievas and Kerem Nişancioğlu's contribution to the debates on the emergence of capitalism and the rise of 'Western power' can be described as an attempt to internationalize the origins of capitalism and rise of Western Europe while providing considerable reasons for the decline - or at least growth plateau - of 'Eastern civilizations' (e.g. Chinese, Mongolian, and Ottoman). Their analysis reflects existing debates on the need to challenge Eurocentric historiography that not only views the development of capitalism as internal to Europe but that also understands the development of captialism as a linear progression (Banaji 2007; Bhambra 2009; 2010; 2011; Chakrabarty 2000; Chalcraft 2005; Goody 2006; Shilliam 2004; Tansel 2015). They argue that:

\begin{abstract}
...the origins and history of capitalism can only be properly understood in international or geopolitical terms, and that this very 'internationality' is constitutive of capitalism as a historical mode of production. The existing conceptions of capitalism have hitherto failed to take this internationality seriously (2015: 2).
\end{abstract}

Anievas and Nişancioğlu suggest that mainstream scholarly accounts see the 'other' or nonEuropean societies and populations as backward, unimportant and passive agents in the constitution of world capitalism (to our knowledge the foundational critique belongs to Wolf 1982). These traditional accounts display an implicit and sometimes more overt form of white 
supremacy in their analyses where the 'East' is/was dependent on Europe's so-called benevolent civilizing mission (Bowden 2004; 2009; Losurdo 2011). Anievas and Nişancioğlu want to intervene with a counter-history that argues for the importance of colonialism, slavery, patriarchy and imperialism in the geopolitical constitution of European capitalism. Through Leon Trotsky's concept of uneven and combined development, they try to demonstrate that capitalism as a mode of production was co-constituted by many international determinants - particularly those emanating from the 'East'. At its most basic, the concept of uneven and combined development is the idea that many human communities were formed around the world with varying cultures, cosmologies and practices of social reproduction (uneven variation). Over time, these communities come to interact with one another in various ways (culturally, economically, politically, and violently) and this leads to social change (different combinations). This concept leads Anievas and Nişancioğlu to a number of observations of which we mention only the two major below.

First, Anievas and Nişancioğlu provide various examples that demonstrate how 'Pax-Mongolica' helped European societies' capitalize on their 'backwardness.' An example of this is evident when the Mongols destabilized China whereby the Ming Empire had withdrawn their powerful merchant and naval fleet from the Indian Ocean (allowing Portuguese and Dutch 'easy access' to Eastern commercial markets). They were also able to securitize and stabilize trade routes (for merchants) 'between the East and West.' This, in turn, 'facilitated the diffusion of such key military technologies as navigational techniques and gunpowder from East Asia to Europe - all of which were crucial to Europe's subsequent rise to global prominence' (2015: 69). Finally, due to increased trade, the Mongols also unintentionally brought the Black Plague into the heartland of Europe - an event, for which most historians take as a focal 'take-off' point for the transformation of English social property relations that led to capitalism (2015: 78ff).

Second, the authors see a key role for the Ottoman Empire in co-constituting the birth of capitalism. Here they argue that the Ottoman Empire was capable of defending itself from the imperial threat of the Habsburgs, partially closing off access to easy trade routes to the Eastern trade. These obstacles to lucrative markets in the East forced European merchants to look for alternative routes. Over time, this meant 'a structural shift to Atlantic trade and Northwestern 
European dominance, leading to processes of developmental "catch up" and overtake in Europe that would give rise to capitalism' (2015: 94). Put simply, the strength of the Ottoman Empire contributed to, if not caused, the development of a European led transatlantic economy that spurred greater capitalist development.

However, the authors do not stop at critiquing Eurocentric cum Liberal triumphalist historiography, their main target appears to be two main strains of Eurocentric Neo-Marxism: World Systems Theory and Political Marxism. The dispute between these two camps is largely 'whether the intensification of exchange relations (trade) or class conflict was the prime mover in the transition to capitalism' (Anievas and Nişancioğlu 2015: 7 our emphasis). ${ }^{1}$ Anievas and Nişancioğlu argue that while World Systems Theory views the development of capitalism through an international lens, it (in particular Wallerstein) misses the historical specificity of capitalism's emergence while at the same time underplaying the agency of Europe's periphery (Anievas and Nişancioğlu 2015: 14). For its part, Political Marxism, according to Anievas and Nişancioğlu, often over-emphasizes the transformation of social property relations in the transition from English feudalism to the capitalist mode of production. Thus, they charge that Political Marxism 'freezes capitalism's history' in England, also leading to a form of Eurocentrism insofar as the analysis of capitalism's development is singularly focused on class struggle in England (Anievas and Nişancioğlu 2015: 24). It should also be mentioned that they critique Post-Colonial Theory for under-acknowledging the cross-fertilization and influences between various 'Western' and 'Eastern' societies.

To right these mistaken approaches, Anievas and Nişancioğlu attempt firstly to eliminate the conceptual binary of 'East and West' and secondly, to determine how pre-capitalist social relations in various Eastern Empires shaped and reshaped the geopolitical origins of capitalist modernity (i.e. Mongol and Ottoman). Unlike the two neo-Marxist perspectives summarized above, the authors adopt a Neo-Marxist perspective that sees geopolitical interaction as a fundamental factor of the transition to the capitalist mode of production. Firstly, parts of Europe, especially England and the Netherlands, were able to 'capitalize' on their 'privileges of

\footnotetext{
${ }^{1}$ The choice of words here is interesting given our discussion of the importance of coal energy later in the article. The term 'prime mover' is an engineering or scientific term for any machine that converts energy into mechanical energy, typically for motive power.
} 
backwardness' to transform and 'develop' their societies 'faster' in order to be competitive with the 'East' which Anievas and Nişancioğlu claim had more 'advanced' societies. Secondly, because the 'East' was more 'advanced' than Europe, the authors' reason that 'Eastern' societies were constrained by their very progressiveness. Anievas and Nişancioğlu attribute this inability to 'progress' further to the complexities of hierarchy and the social reproduction of these hierarchies. In this way the authors argue strongly that the concept of uneven and combined development helps scholars de-centralize Eurocentric renderings of capitalism and the "rise of the West. ${ }^{2}$ We will leave it to other scholars to debate the precise merits of the concept of uneven and combined development but of the geopolitical origins and connected histories of capitalism there can be little doubt. Anievas and Nişancioğlu's work should be applauded for its focus on interconnections and reviving the importance of colonialism, patriarchy, slavery and imperialism in the constitution of capitalism and European power. However, tracing the origins of something - geopolitical or otherwise - requires an analytical definition of what we are seeking to find. It would be absurd to go searching for a 'dog' if we had no clue what the term 'dog' refers to. This is where we argue that Anievas and Nişancioğlu have an inadequate and misleading understanding of 'capital' and 'capitalism' that tilts them towards a theoretical stance that comes very close to arguing that everything caused capitalism, is capitalism or contributed to the emergence of capitalism all the while having no convincing definition of 'capital' or 'capitalism'. We turn to this argument in the next section.

\section{Of Capital and Capitalism}

In their work, Anievas and Nişancioğlu provide no precise analytical definition of what capital is, how it is accumulated and for what purposes. They do, however, state that 'capital' is not a 'thing' like a machine, a pool of money or profit and eventually settle on the idea that capital is a social relation between owners of the means of production and wage-workers (2015: 8). Yet, since wage-labor remains central to their ontology of capitalism and they claim to follow Marx,

\footnotetext{
${ }^{2}$ In their words: '...how the asynchronic simultaneity of a plurality of existing societies (unevenness) came to interact in ways that generated further substantive sociological differences (geopolitical combinations), in turn leading to sharp divergences in their developmental trajectories. This is in fact a hallmark of any inter-societal system: they are generatively differentiating through the very interactive plurality of their units' (Anievas and Nişancioğlu 2015: 250).
} 
we are lead to the contradictory claim that 'capital' is in fact a material entity or a 'thing'. Sorting out this confusion requires some explaining. ${ }^{3}$

In the annals of political economy there are only two theoretical traditions that provide us with clear, albeit mistaken, analytical definitions of capital. The first is the neoclassical school of Economics that understands capital largely as a material entity (though ideas/technology are sometimes included) used in production. For example, one of the most widely used textbooks argues that capital 'is the set of tools that workers use: the construction worker's crane, the accountant's calculator, and this author's personal computer' (Mankiw 2010: 47). So in this formulation, it follows that if we are accumulating capital we are attempting to get ahold of more and more factors of production over time. Obviously, this is not what capitalists pursue as an end goal and so, despite other problems, we can dismiss this definition as rather absurd or incorrect. The second definition of 'capital' stems directly from Marx and was absorbed by the Marxist tradition uncritically. Though we share many affinities with this tradition - particularly the will to historicize the present - we have to first understand that Marx had a split personality. The first is Marx as historian, concerned to demonstrate that the origins of capitalism lie in the dispossession or expropriation of peasants from their means of subsistence, thereby creating the potential for the exploitation of wage-labor. The second is Marx the- would-be scientist (he tried to dedicate the first volume of Capital to Darwin but Darwin refused the gesture) who believed that capitalism had laws of motion that could be uncovered and understood. Identifying these 'natural' laws of motion is supposed to contribute to our ability to predict future outcomes - in Marx's case, the emergence of communism out of the contradictions of capitalism. It is Marx the scientist, not Marx the historian, who provided us with a definition of capital as surplus dead labor (Di Muzio 2014: 3). The two most relevant passages are:

Capital is dead labour, that, vampire-like, only lives by sucking living labour, and lives the more, the more labour it sucks. The time during which the labourer works, is the time during which the capitalist consumes the labour-power he has purchased of him (1867: 160).

\footnotetext{
${ }^{3}$ The confusion begins with Marx who thinks of capital as a 'social relation'. But when he comes to define it analytically to explain exploitation in the workplace, 'capital' becomes 'dead labor' or machines/objects that produce commodities.
} 
And

But it is only in the factory system that this inversion for the first time acquires technical and palpable reality. By means of its conversion into an automaton, the instrument of labour confronts the labourer, during the labour-process, in the shape of capital, of dead labour, that dominates, and pumps dry, living labourpower. The separation of the intellectual powers of production from the manual labour, and the conversion of those powers into the might of capital over labour, is, as we have already shown finally completed by modern industry erected on the foundation of machinery (1867: 282 our emphasis).

In other words, though a bit more philosophically sophisticated than the neoclassical economists, 'capital' is understood as material things used in the production process of commodities. The reason why Marx offers a slightly more sophisticated account is because he argues that the only thing that can produce more value in the process of producing commodities is human-labor power - essentially the capacity to work. From a philosophical vantage point, Marx argued that when this labor-power is expended in production it is objectified or turned into material things or more accurately factors of production that help produce commodities. In sum, capital is dead labor/machines and therefore from a Marxist point of view, when we say we are accumulating capital we must mean we are accumulating more material things able to help us produce commodities. This is taking Marx seriously and at his 'scientific' word. But of course, in actual reality, no capitalist pursues the accumulation of evermore machines or evermore laborers. We would hope that Anievas and Nişancioğlu agree with us that there can be no doubt that what capitalists really want is more differential power measured in money, not more machines or factors of production as an end goal. Marx undoubtedly knew that the goal was to get evermore money, but his definition of capital committed him to viewing it as a material entity rather than an abstract register (money units) of social power. But why do both schools have a demonstrably inaccurate understanding of 'capital'? Part of what helps to explain the neoclassical and Marxist confusion is the misunderstanding of the term 'capital' in Adam Smith's The Wealth of Nations, which both traditions adopted in their own way.

Now, there is little doubt that the etymology of the term 'capital' has deep historical roots which are of some interest (on the etymology which we do not trace here see Braudel 1983: 232ff). 
However, what seems clear is that in business vernacular before the Wealth of Nations (1776), capital meant a sum of money to invest or alternatively, a sum of money already invested in expected profitable activities. We should take note that it is investment in 'profitable activities' that matter, not factory production per se. As Cannan argues, it was Adam Smith who created considerable confusion when he redefined capital as material goods used in production. This was a 'very serious departure from the conception of capital which had hitherto prevailed. Instead of making the capital a sum of money which is to be invested, or which has been invested in certain things, Smith makes it the things themselves' (1921: 480 our emphasis). This conceptual error has certainly been passed down to neoclassical Economics and with some considerable philosophical finesse, to Marxism as well. Both neoclassical Economics and Marxism understand capital as a material entity used in production, albeit quantified in a monetary unit. In this way, the accumulation of 'capital' in neoclassical Economics is the accumulation of factors of production and for Marxists, the accumulation of dead labor or instruments used in the production of commodities. ${ }^{4}$ This is likely why there is considerable conflation of the terms 'industrial revolution' and 'capitalism' - particularly in the Marxist literature. Clearly, there's a big problem with both understandings since capitalists want to have their capitalization (measured in a monetary unit of account) rise faster relative to others and industrialization, as the Soviet Union demonstrated, does not have to follow any capitalist logic.

As we have suggested, if we are looking to contribute to debates on the geopolitical origins of capitalism than it would be a good idea to have both a sound and convincing analytical definition of 'capital', not to mention a clear definition of 'capitalism'. As it turns out, the definition of 'capitalism' provided by Anievas and Nişancioğlu is even more muddled than their understanding of 'capital':

...capitalism is best understood as a set of configurations, assemblages, or bundles of social relations and processes oriented around the systematic reproduction of the capital relation, but not reducible - either historically or logically - to that relation alone. By placing an emphasis on such configurations and assemblages, we also seek to highlight how the reproduction and competitive accumulation of capital through the exploitation of

\footnotetext{
${ }^{4}$ Technically, for neoclassical Economics it is the accumulation of 'utils' or units of satisfaction.
} 
wage-labour presupposes a wide assortment of differentiated social relations that make this reproduction and accumulation possible (2015: 9 our emphasis on the word capital). ${ }^{5}$

This passage is brimming with considerable confusion. First, we are told that capitalism is best understood as 'relations and processes' that help reproduce the capital relation - which Anievas and Nişancioğlu tell us is the relationship between wage-laborers and capitalist owners of the means of production. We are then warned not to see this relation as the only important social relation. We are asked to consider how 'a wide assortment of differentiated social relations' helped to reproduce the dominant relation and makes the accumulation of capital possible. This is akin to throwing everything at the wall to see what sticks, except that everything sticks: virtually everything caused and/or supported capitalism or is itself capitalism - the reader is left to his or her own devices to sort out the confusion. Secondly, we are once again accumulating 'capital' or dead labor/machines and while we are told that other 'relations and processes' are important, the accumulation of capital is achieved through 'the exploitation of wage-labour'. Thus, this passage also suggests that there is no accumulation of 'capital' outside the exploitation of wage-labor, which obviously flies in the face of history and seems to contradict their argument that colonial enterprise and the slave trade were important for the rise of capitalism.

In the end, we are left with highly unconvincing analytical definitions and are forced, if we are to interpret and understand the geopolitical origins of capitalism, to find a convincing alternative. We argue that the convincing alternative can be found in the Capital as Power approach to international political economy introduced by Jonathan Nitzan and Shimshon Bichler (2009).

\section{Capital as Power}

The Capital as Power approach has a clear definition of capital as 'commodified differential power' measured in money and avoids any 'mode of production' theorizing. Rather than focus on industrial production and the particular organization of workers within a firm, the focus is on capitalism as a mode of power and this means a keen focus on the act of capitalization rooted in ownership. Capitalization is the chief ritual of capitalism and it has two meanings. First, it is the

\footnotetext{
${ }^{5}$ The remainder of the quote goes on to say: 'These relations may take numerous forms, such as coercive state apparatuses, ideologies and cultures of consent, or forms of power and exploitation that are not immediately given in or derivative of the simple capital-wage-labour relation, such as racism and patriarchy' (Anievas and Nişancioğlu 2015: 9).
} 
act of discounting to present value an expected future flow of income adjusted by some factor of risk. The primary reason why this act is done by owners/investors is because of the time value theory of money. This simple theory argues that a unit of currency (e.g. dollar, Euro, Yen), is worth more today than it is tomorrow because it can start generating interest sooner. This is why capitalists discount future flows of income and it should be noted that anything that generates an income stream can, at least theoretically, be capitalized. The second definition of capitalization when applied to corporations is the market value of the firm. This is easily calculated by taking the number of shares outstanding and multiplying it by the price of one share at any given point in time. Shares in companies represent a claim to future earnings with the overall value of capitalization fluctuating based on expected earnings and actual earnings when they are reported. Poor earnings or returns typically send share prices down while meeting and beating earnings expectations sends the perceived money value of the company up. Yet, unlike the neoclassicals and their Marxist counterparts, the Capital as Power perspective argues that earnings are not a narrow offshoot of producing commodities, but the result of a broader power process that shapes and reshapes the terrain of social reproduction. For example, Apple's capitalization is not simply contingent on producing iPhones, tablets, computers etc. but on a range of social power processes from advertising to trade and labor laws to intellectual property protection by governments - all these factors and more bear on its earnings. We should also point out that capitalization is not 'fictitious capital' - a point which has confused Marxists for over a century but purchased ownership claims to future flows of income. Thus, when we capitalize Apple (buy equity in the company), we are in essence capitalizing Apple's power to shape and reshape the terrain of social reproduction in ways that generate better earnings than its rivals in the corporate universe. This is also true for every capitalist firm listed on an exchange. The difference, however, is the organized differential power of corporations and those who own them. What this suggests is that corporations with the highest levels of capitalization (market value) have greater power to shape and reshape the terrain of social reproduction in their favor to generate differential earnings. And since these ownership claims are tradable or vendible, this is why capital is defined as commodified differential power measured in a money of account. Thus, when we talk about 'accumulation' in the Capital as Power framework, we mean rising capitalization of owned income generating assets (the monetary value of claims to future income) regardless of the composition of the assets. With this in the background, we are now in 
a position to define the term 'capitalism'. Capitalism is a politico-economic system premised on the social property relations between hierarchically arranged owners and non-owners whereby income-generating assets are differentially capitalized based on the institutional power of business and governments to generate income streams by shaping and reshaping the landscape of social reproduction through the market and price system. ${ }^{6}$ To be a capitalist then, is to be an owner/investor in income generating assets with the difference between capitalists largely stemming from the monetary value of their capitalization or claims on future earnings. By social reproduction we mean the way any society produces, consumes and reproduces its lifestyles, how it conceives of these lifestyles and how they defend them juridically or through the application of violence. In this way, the Capital as Power approach to international political economy has no difficulty whatsoever in seeing how different forms of labor, as well as different forms of discrimination and exploitation can coexist historically - a benefit claimed by Anievas and Nişancioğlu for uneven and combined development perspectives. For example, slaves are non-owners of any income generating assets, including their own labor. But transatlantic slavery was a wholly capitalized enterprise from the for-profit companies who transported and sold slaves in the Americas and Caribbean to the work done on plantations. To take but one example of many, consider that most of the Southern planters who would eventually lead the American Revolution were deeply in debt to Northern and British financiers (Thomas 1993: 52). In effect, these financiers were capitalizing the work of slaves for profit on plantations as slave masters repaid their mortgages (among other debts) at interest to their creditors (Baptist 2014). More than this, the slave system in the United States and elsewhere also helped erect an international economy enabling the further capitalization of additional income streams (e.g. tobacco, sugar, cotton, iron). Marxists have to get out of the factory floor and come to see the world how capitalists actually see it: from the point of view of capitalization.

\section{The Geopolitical Emergence of Capitalism}

With clear definitions of 'capital' and 'capitalism' we are now in a position to explore some of the conceptual silences and significant historical omissions in How the West Came to Rule. To do so, we will not be looking for a precise birthday for capitalism since the history of

\footnotetext{
${ }^{6}$ There is no separation between an 'economic' sphere and a 'political' sphere in the Capital as Power approach, they are theorized as fused as they are in daily practice.
} 
capitalization, while somewhat traceable, is considerably obscure (Nitzan and Bichler 2009: 147ff). We argue that what is important to uncover are the conditions 'that contributed to the intensification (increasing orders of magnitude) and extensification (socio-spatial scope) of capitalism' to the point where total outstanding world capitalization is US\$294 trillion - most of which consists of debt instruments (Di Muzio 2015: 48). ${ }^{7}$ Surely all the factors that allowed for this massive increase in capitalized income-generating assets is overdetermined, but are there identifiable major factors, without which, we will fail to explain the development of capitalism in a convincing way? We argue that there are such major factors and we consider three below that are omitted from How the West Came to Rule: the financial revolution and the creation of the Bank of England, the transition to coal energy and the capitalization of the state as it relates to international warfare, colonialism and Atlantic slavery.

\section{The Importance of Credit/Money Creation}

If capitalists are mostly concerned to accumulate more money units faster relative to those trying to do the same, it would be a reasonable idea to understand where money comes from and how it is produced. What is too often underappreciated is that in the $17^{\text {th }}$ century in England there were extensive debates on the dearth of money. As Wennerlind puts it "while modern economic theory does not recognize the possibility of a scarcity of money, seventeenth-century thinkers were consumed by this problem' (2011: 17 our emphasis; see also Di Muzio and Robbins 2016). Indeed, even by the time of Adam Smith it was common to note that "no complaint, however, is more common than that of a scarcity of money' (1776: 348). While there were other forms of money in circulation by the $17^{\text {th }}$ century such as tokens and tallies, the most dominant form of money was thought to be silver and gold (Davies 2002; Ingham 2004). Gold and silver forms of coined money were particularly coveted by rulers and merchant capitalists to finance military operations abroad and purchase goods predominantly produced in Asia. Since Asians did not particularly desire European goods in considerable quantities - and even less so the goods produced in England - many Asian rulers would only trade for silver, gold or their representatives (e.g. paper bills). The difficulty was that there was a dearth of silver and gold in England in the seventeenth century if not before. One of the reasons for the constant search for

\footnotetext{
${ }^{7}$ http://www.marketwatch.com/story/global-stock-market-cap-has-doubled-since-qes-start-2015-02-12 The figure is for 2014 and as yet has not been updated by McKinsey. (4/14/2016).
} 
coin was that, while English merchants and slave-runners were bringing coin into the realm from the increasing Atlantic trade, considerable amounts of coinage subsequently left England for Norway, Sweden and the Baltic to pay for imports of timber and iron ore (Thomas 1993: 60 and 74). Thomas captures the interconnections:

Britain's huge favourable trade balance with Portugal was settled in bullion from Brazil whose gold shipments to Portugal increased from $£ 350,000$ in 1700 to $£ 2,200,000$ in 1760. (Fisher 1969:153) Large gold imports into England, based on the rapid growth of Brazil's slave economy, 1695-1750, helped to make London the financial centre of Europe and contributed to the financing of the crucial imports of iron, timber and naval stores from the Baltic (199: 37).

Without access to this timber and iron for fuel and the construction of ships, the Cromwellian naval revolution that ignited the capitalist British Empire would not have taken place. The money problem had to be solved. At first, intellectuals associated with the Hartlib Circle - an early scientific correspondence society that spanned some of Europe - thought they could create silver and gold by alchemy. The Hartlib Circle was not so concerned with the eastern trade but with the discourse of improvement and the possibility of ever greater productive change (Wennerlind 2011: 44ff). The problem, as they understood it, was liquidity: how could the money supply be increased to circulate more goods and services if 'real' or 'dominant' money was thought to be only gold and silver coins? Failing alchemy, there were only a few ways the metallic money supply could increase: 1) find new mines at home or abroad, 2) plunder the metals from others, 3) debase the currency (less metal per coin), and last, 4) ensure a trade surplus with foreign countries (more coins enter than exit the country). However, as Wennerlind argues, what eventually occurred was an epistemological revolution. It was finally discovered that money need not be metallic coins per se. This realization freed thinking on the liquidity issue and lead to considerable debate on how to set up an institution that could issue credit that could act as money. There were multiple proposals of how this could be done, but in the forcing house of European geopolitics and near constant warfare, a decision was made to accept the proposal of London financiers to institute a Bank of England (Davies 2002: 255ff and Horsefield 1960). In 1694, six years after the so-called Glorious Revolution that installed William of 
Orange and Mary II to the throne of England, William Paterson's proposal was institutionalized. Many believe it was the Dutch influence on English finance that inspired the creation of the Bank of England. But whatever the English may have learned from Dutch finance and fiscal policy, all evidence points to the fact that the Bank of England operated in quite a different way than the Bank of Amsterdam (Vilar 1984: 204ff and 211ff). The latter never actually extended the money supply, generally keeping a one to one ratio of notes and coin (Wennerlind 2011: 128). The Bank of England, however, did extend the money supply over and above the silver coin it had on hand, thereby increasing the money supply. The act of creating new currency as credit to the King-in-Parliament did not totally overcome the dearth of money problem, but there is little doubt that it expanded the money supply and helped to finance the War of the League of Augsburg based on a permanent loan - a fact that we will return to below when we discuss the capitalization of the state (Davies 2002: 259). Thus, the establishment of the Bank of England, and later additional provincial banks issuing their own money as credit helped to expand the money supply that supports industry, trade and the accumulation of more money/capitalization and power. As Wennerlind observed:

Noting that England already possessed all the natural, economic, and human resources required for great prosperity and geopolitical strength, Mackworth argued that with the establishment of the Bank, the nation was now capable of capitalizing on this potential. "Our Country," he argued, "thus accomplish'd with all Blessings, as to Fertility and Ingenuity, a little help [from the Bank] will make it the most Glorious Place in the World, and His Majesty the most Potent Prince in Christendom." He argued that the bank was first to settle "the Great Question . . . [of] How to raise a Stock or Fund that shall be credited by all." The fact that the Bank's notes were assignable by law and secured by Parliament's power to tax ensured that the notes would retain their value and thus be able to serve as a pledge in market exchanges (2011: 112-113). ${ }^{8}$

Thus, omitting the source of new money creation is a significant oversight, particularly because 'the Bank's notes circulated at par from the start, signaling the arrival of England's and Europe's

\footnotetext{
${ }^{8}$ Sir Humphrey Mackworth (1657-1727) was an industrial entrepreneur.
} 
first widely circulating credit currency (Wennerlind 2011: 109 our emphasis). But here we arrive at a crucial question: why was the dearth of money question so crucial to answer in England by the $17^{\text {th }}$ century and why ultimately did this solution work to increase liquidity when Law's somewhat similar scheme failed in France? We might also ask why Spain and Portugal, who imported boatloads of gold and silver did not experience a more fully capitalist and productive manufacturing economy? We find sufficient evidence to suggest that the answer lies in the dearth of wood and the capitalization of the state.

\section{The Importance of Coal Energy}

If as Wennerlind points out, the dearth of money problem consumed intellectuals in England at least by the $17^{\text {th }}$ century, it was equaled by a concern over the shortage of wood. Like Marx, Marxists have traditionally treated energy as an auxiliary in production and as a result have largely ignored the fact that England was the country to go through a massive energy transition to non-renewable coal energy (Debeir et al 1991: xiii). ${ }^{9} \quad$ The question is why the English turned to coal more intensely than any other political community on the planet? The answer is that at least in the seventeenth century if not well before, there was an energy crisis in England. (Cipolla 1997; Fouquet and Pearson 1998; Goldstone 2002; Malanima 2006; Nef 1997; Podobnik 2006; Smil 1994: 159; Thomas 1986; Wrigley 2010). The English had denuded most of their forests for fuelwood, charcoal to make iron implements, boats, homes, cities and weapons among other things. The available evidence is canvassed in Di Muzio (2015: 62ff) but perhaps the biggest indicator of historical change is the fact that the cost of timber was skyrocketing well above the price for timber in neighboring France and well above general prices in England (Williams 2006: 153). In this situation, as well as if elites wanted to compete for a share of the world's wealth geopolitically and not have her security threatened, England was basically forced to rely on domestic coal as a primary energy source. This reliance massively increased the energy available to England (and Great Britain after 1707) and had a number of knock-on effects that would eventually lead to an expanding money supply and the greater capacity to produce goods and services, particularly but not exclusively, pig iron. The only other

\footnotetext{
${ }^{9}$ Marx clearly states: 'Raw material may either form the principal substance of a product, or it may enter into its formation only as an accessory. An accessory may be consumed by the instruments of labour, as coal under a boiler, oil by a wheel, hay by draft-horses, or it may be mixed with the raw material in order to produce some modification thereof' (1887: 127).
} 
major producers in Europe - Belgium, France and Germany - which took to coal production comparatively late, produced far, far less than Britain even by 1850-4 when the steam engine was beginning to be used more frequently in industry (Wrigley 2010: 98-99). In other words, Great Britain was the first nation to undergo a fossil fuel energy revolution and found a global empire on the surplus energy provided by coal. In fact, the first practical steam engine - the sine qua non of the industrial revolution because it helped increase the capacity able to be capitalized - which ran on coal, was largely invented by an ironmonger to solve the problem of pumping water out of coal and tin mines more effectively (Allen 2011: 375). The trouble of actually getting coal and tin out of the pits lead to the idea of railways, which over time, revolutionized global transportation and facilitated colonial capitalist exploitation as railway construction internationalized (Davis and Wilburn 1991: 3; Smil 1994: 160). We should not underestimate this point as Hick reminds us:

[Early cotton machinery] fits better as an appendage to the evolution of the old industry than in the way it is usually presented as the beginning of the new.... There is continuity between the eighteenth-century development of Lancashire and the West Riding and the pre-Industrial Revolution world. There might have been no Crompton and Arkwright, and still there could have been an Industrial Revolution (cited in Cipolla 1977: 211). ${ }^{10}$

It is for this reason why we argue that Britain can be conceived of as the first fossil fueled market civilization with a rising money supply backed by the surplus energy capacity provided by its reliance on coal (Di Muzio 2015; Gill 1995). Expanding the money supply - as in France, Spain and Portugal - without adding manufacturing capacity largely resulted in rising prices for a limited amount of goods produced by an organic, not fossil fueled, economy.

It is here where we should give pause and consider the argument most forcefully put forward by the Political Marxists that a revolution in agrarian social property relations was required for the birth of capitalism. The main idea here is that waves of enclosure and the loss of customary access to the land in the English country-side expropriated a significant portion of the peasantry

\footnotetext{
${ }^{10}$ Sir Richard Arkwright is credited with having patented the spinning/water frame while Samuel Crompton is credited with developing the spinning mule.
} 
(class war) and forced them to work for wages in order to meet their subsistence needs. The threat of hunger, as most elites realized at the time, was a spur to work for the non-owning class (Polanyi 1957: 90-92). After the Norman Conquest (1066) more and more rents were commuted to money rather than in kind, and this contributed to a competitive market in leaseholds (Smith 1776: 28). ${ }^{11}$ If capitalist tenant farmers and their waged workers did not produce according to the expected future yield of the land surveyor, they could lose their leasehold and therefore their livelihood (Wood 2002: 101ff). The corollary is that this competitive atmosphere, combined with the desire of landlords to improve their returns on the land led to greater growth, innovation and improvements. But while we can admit that farming practices did improve due to the competitive environment for leaseholds and the pressure introduced by the surveyor's estimates, no amount of human labor on a farm or pasture alone could have contributed to the intensification (increasing orders of magnitude) and extensification (socio-spatial scope) of capitalization. Without the mass exploitation of coal across the economy, Britain would have remained like the rest of the world - an organic economy whose social reproduction remained chained to the rhythms of photosynthesis and limited energy stores and flows. Moreover, the dispossession that occurred in the countryside did not lead to capitalists exploiting a newly created class of wage reliant workers in their entirety. As is well documented, the primary result of the great expropriations was not mass proletarianization but mass pauperization and the criminalization of the poor (Marx 1867: section 8; Polanyi 1957: 90-92). So while the Political Marxists are correct that a revolution in social property relations did take place thanks to the enclosure movements - a qualitative break with the past not simply a quantitative increase of money/goods - they are vastly mistaken that this and this alone would have led to an increase in industrious capacity and greater capitalization over time. The enclosure movement was indeed a class war, but it was one that primarily solidified ownership over sheep pastures and arable land while creating a majority class of non-owners with the capacity and incentive (hunger) to work for a wage (Thomas 1993: 67). But there is still one more revolution that contributed to the development of capitalism: the capitalization of the state and how this capitalization related to war, colonialism and the transatlantic slave trade.

\footnotetext{
${ }^{11}$ Smith write that: 'The revenues of the ancient Saxon kings of England are said to have been paid, not in money, but in kind, that is, in victuals and provisions of all sorts. William the Conqueror introduced the custom of paying them in money. This money, however, was for a long time, received at the exchequer, by weight, and not by tale.'
} 


\section{The Capitalization of State Power and War, Colonialism and Slavery}

We agree with Anievas and Nişancioğlu's argument that war played a crucial role in the constitution and reconstitution of capitalism and the so-called rise of the 'West' but we believe they downplay its role when it should be elevated to primary importance given the scale of the enterprise and the fact that it was the chief contributor to the capitalizable national debt (Brewer 1989). We suggest that it is very difficult to understand how war contributed to the development of capitalism without understanding the capitalization of the state. Marx recognized this fact, but he never developed it:

The system of public credit, i.e., of national debts, whose origin we discover in Genoa and Venice as early as the Middle Ages, took possession of Europe generally during the manufacturing period. The colonial system with its maritime trade and commercial wars served as a forcing-house for it. Thus it first took root in Holland. National debts, i.e., the alienation of the state [by sale] - whether despotic, constitutional or republican - marked with its stamp the capitalistic era. The only part of the so-called national wealth that actually enters into the collective possessions of modern peoples is their national debt. (1867: 529).

The role of the national debt is crucial for understanding the development of capitalism and war as interconnected, as it remains today. For example, the United States has the world's largest military, spends the most money on the preparation for war or fighting war and also has the world's largest national debt. While the dearth of money problem spurred debate on monetary reform it should always be remembered that the ultimate solution - the creation of the Bank of England - was institutionalized not just to create credit money for the sake of commerce but primarily to finance war against France:

The Bank of England came into being by the Ways and Means Act of June 1694 and was confirmed by a Royal Charter of Incorporation (27 July 1694). The Act makes it clear that its real purpose was to raise money for the War of the League of Augsburg by taxation and by the novel device of a permanent loan...(Davies 2002: 259). 
The Bank of England capitalized the state to the tune of $£ 1,200,000$ in return for an 8 per cent annual return plus a yearly management fee of $£ 4,000$ (Davies 2002: 260; Wennerlind 2011: 108ff). The Bank's notes were redeemable in coin but the Bank's inventor - William Paterson understood that only a small percentage of silver coin (15 to $25 \%$ ) was needed to ensure the confidence in the use and circulation of the notes (Wennerlind 2011: 110). While we will likely never know the amount of money that actually backed up the notes issued by the Bank of England, even at the high end of $25 \%$ backing it would be $£ 300,000$ of silver. To help finance this operation and lend confidence to the Bank's investors, the Parliament introduced a new tax on alcohol and shipping. This was to be the direct stream of income capitalized by the 1300 domestic and international investors in the Bank of England but in effect, the investors were capitalizing far more. From the point of view of Capital as Power, what the investors had actually capitalized was the power of Parliament to wage war, tax the population and to punish those who refused such taxation. Trust in this new fiscal system - as the liberals are wont to stress - was also backed by a new constitutional order that made the monarchy subordinate to Parliament. But we should also recall that this financial revolution was also backed by a recoinage of silver overseen by Isaac Newton and a penal system with vicious punishments for coin clippers and counterfeiters (Wennerlind 2011; McNally 2014). The tradeable "national debt' backed by Parliament's power to tax, wage war and punish offenders was at the center of British capital markets as it established a normal rate of return or a benchmark with which to help value other investments in the emerging join-stock enterprises. At the same time, as Dickson's (1967) work has shown, the financial revolution helped fund external imperialism and internal economic growth. And as is well known, the British 'national' debt became the center of global finance as the 'national' debts of other countries were listed on the London Stock Exchange and British capital financed foreign exploits (Attard and Dilley 2013; Hobson 1902; Johnston 1935; Michie 2001). ${ }^{12}$ To be sure, over time, the desire of the British ruling class to fight continental and colonial wars along with support the transatlantic slave trade was a major factor in calling forth greater steel and coal/energy production, a mounting national debt and a vast array of newly capitalizable productivity. All four were brought together under a strong naval policy during the time of Cromwell and as wars increased in frequency and expense after 1688 , the policy only strengthened. Brewer gives us a glimpse of its importance:

\footnotetext{
${ }^{12}$ See also the special issue of The Journal of Imperial and Commonwealth History, Vol 13, I 31985.
} 


\begin{abstract}
Naval dockyards were, by the standards of the day, immense enterprises. They were the largest industrial units in the country, dwarfing their nearest rivals, the breweries and the mines. During the War of Austrian Succession, for example, the Portsmouth dockyard employed a workforce of over 2000. By the 1770s the total labor force in naval dockyards had reached over 8000, with half of these men working at Portsmouth and Plymouth. The navy was thus one of the largest single employers of civilian labor in eighteenth-century England. Naval ships and shipbuilding operated on a scale quite unlike that of civilian industry and commerce. Capital and labor were deployed in a manner that was beyond the resources of the merchant or manufacturer. Only the state could undertake enterprises on such a scale (1989: 28 our emphasis).
\end{abstract}

This passage not only demonstrates the scale of the enterprise but points to the fact that it is an historical absurdity to see any separation between 'capital' and the 'state', both are fused through the process of capitalization. ${ }^{13}$ As Nitzan and Bichler assert:

In fact, state and capital were always symbiotic, coalescent, and often fused. The modern nation state, from its very beginning, was highly dependent on capitalist finance, while capitalization was similarly reliant on state power. Indeed, it was this fusion between them which gave rise to the first form of modern capital - the government bond...(202: 13)

What is more, to emphasize the importance of war-fighting and the preparation for war in the origins of capitalism consider the fact that the total fixed capital invested in 243 mills working in the West Riding woolen industry was a mere $£ 402,651$ by 1800 whereas the figure is $£ 2.25$ million in 1750 for the Royal Navy. As Brewer observes, the 'fixed capital in one of the largest sectors of the nation's most important industry [wool] was therefore a mere 18 per cent of the fixed capital required to launch the British navy (1989: 27). Thus, it cannot be stressed enough that in Britain the largest capitalized entity was the state and its capacity for war and taxation and continues to be the state and its capacity for war along with its overall ability to generate an

\footnotetext{
${ }^{13}$ Anievas and Nişancioğlu do notice the importance of shipbuilding but it is fairly underplayed and its links with energy and the capitalization of the state and the eventual creation of a 'national' debt are ignored.
} 
income stream from its regulation of a growing economy. For example, the British state is capitalized at US\$3 trillion while its largest company, Royal Dutch Shell is capitalized at about US\$133 billion. The last thing to note in this section is that other than the Bank of England and the British government, there were only two other major capitalized entities until the eighteenth century: the British East India Company and the South Sea Company. In the early eighteenth century, both had capitalized the British government by lending all of their total paid up capital to the state (Michie 2001: 18). Thus, investors were not simply capitalizing the British East India Company's ability to colonize and control trade in India and its neighboring regions or the South Sea Company's monopoly on the slave trade to Spanish America, but through the national debt, also the war-fighting capacity of the state and its (eventually) unparalleled Royal Navy. Moreover, the British East India Company was responsible for imposing a 'national' debt on India during its reign which was linked not just to taxation and public works, but to war (Dutt 1950: chapter X). Di Muzio (2015) discusses the deep interconnections between capitalism and war in greater length elsewhere, but the evidence provided here should be enough to suggest that the capitalization of the British state and its role in facilitating colonialism, war and the slave trade had everything to do with the geopolitical origins of capitalism.

\section{Conclusion: Connected Histories and Capital as Power}

In many ways, Anievas and Nişancioğlu's work has done a great service to critical international political economy in advancing the debates on the emergence of capitalism as a geopolitical phenomenon. It is a considerable accomplishment and while we have stressed some of its omissions rather than its accomplishments, we share their concern for geopolitical origins while also keeping in mind what was peculiar to England and later Great Britain. We have argued that there are two key flaws in their explanation. The first is the unconvincing definition of 'capital' and their conceptually fuzzy definition of 'capitalism'. Received truths and old dogmas die hard but we believe in the power of reason, logic and evidence and hope that those working in the Marxist tradition - who share a critical approach to capitalism along with us - understand that fuzzy or conceptually incorrect definitions of capital and capitalism will seriously hamper our visions of a more humane, progressive and sustainable future and how we might pursue these visions in political action. As Bhambra reminds us: 'the ways in which we understand the past are crucial to our understandings of ourselves and the world in which we live today and...if our 
understandings of the past are inadequate it follows that our grasp of the present will also be inadequate' (Bhambra 2009: 2). What this passage suggests is that if we want to transform or challenge the logic of capitalist accumulation then we ought to have a very good understanding not only of its historical emergence but also of the ongoing process of capitalization. It is within this spirit that we would like to conclude with the idea that we can retain an international and interconnected perspective on the origins of capitalism without sacrificing a convincing definition and explanation of 'capital' and really existing 'capitalism' found in the Capital as Power approach to IPE. Whether Marxists will come around to the view that it is the act of capitalization rooted in ownership that ultimately matters for accumulation and that the magnitude of accumulation, at base, rests on the production and consumption of non-renewable fossil fuels and the control of human labor power remains to be seen. 


\section{References:}

Allen, R. C. (2011) Why the Industrial Revolution was British: Commerce, Induced Invention, and the Scientific Revolution' Economic History Review, Vol. 64, No. 2: 357-384.

Anievas, Alexander and Kerem Nişancioğlu (2013) 'What's at Stake in the Transition Debate? Rethinking the Origins of Capitalism and the "Rise of the West". Millennium: Journal of International Studies Vol. 42, No. 1: 78-102.

Anievas, Alexander and Kerem Nişancioğlu (2015) How the West Came to Rule: The Geopolitical Origins of Capitalism, (London: Pluto Press).

Attard, Bernard; Dilley, Andrew (2013) 'Finance, Empire and the British World' Journal of Imperial \& Commonwealth History Vol. 41 Issue 1: 1-10.

Banaji, Jairus (2007) 'Islam, the Mediterranean, and the Rise of Capitalism', Historical Materialism, Vol. 15: 47-74.

Beaud, Michel (2001) A History of Capitalism, 1500-2000. (New York: Monthly Review Press).

Bhambra, Gurminder K. (2009) Rethinking Modernity: Postcolonialism and the Sociological Imagination. (Basingstoke, Palgrave Macmillan).

Bhambra, Gurminder K. (2010) 'Historical Sociology, International Relations and Connected Histories', Cambridge Review of International Affairs, Vol. 23, No. 1: 127-143.

Bhambra, Gurminder (2011) 'Talking Among Themselves? Weberian and Marxist Historical Sociologies as Dialogues without 'Others', Millennium: Journal of International Studies, Vol. 39, No. 3: 667-681.

Bowden, Brett (2004) 'In the Name of Progress and Peace: The 'Standard of Civilization' and the Universalizing Project', Alternatives: Global, Local, Political, Vol. 29, 43-68.

Bowden, Brett. (2009) The Empire of Civilization: the Evolution of an Imperial Idea. (Chicago: University of Chicago Press).

Braudel, Fernand (1983) The Wheels of Commerce. Civilization and Capitalism $15^{\text {th }}$ to $18^{\text {th }}$ Century. Translated by Sian Reynolds. (London: William Collins Sons \& Co Ltd).

Brenner, Robert (1976) 'Agrarian Class Structure and Economic Development in Pre-Industrial Europe’ Past \& Present No. 7: 30-75.

Brenner, Robert (1977) The Origins of Capitalist Development: a Critique of Neo-Smithian Marxism' New Left Review, No. 104, July-August: 25-92.

Brenner, Robert (1978) 'Dobb on the Transition from Feudalism to Capitalism' Cambridge Journal of Economics 2: 121-140 
Brewer, John (1989) The Sinews of Power: War, Money and the English State: 1688-1783. (London: Unwin Hyman).

Byers, Terence J. (1996) 'Differentiation of the Peasantry Under Feudalism and the Transition to Capitalism: In Defence of Rodney Hilton', Journal of Agrarian Change, 6: 17-68.

Chakrabarty, Dipesh (2000) Provincializing Europe: Postcolonial Thought and Historical Difference. (Princeton: Princeton University Press).

Chalcraft, John T. (2005) 'Pluralizing Capital, Challenging Eurocentrism: Toward Post-Marxist Historiography’ Radical History Review, Vol. 91: 13-39.

Cipolla, Carol M. (1977) Before the Industrial Revolution: European Society and Economy, 1000-1700. Third Edition. (London: Routledge).

Davies, Glyn (2002) A History of Money: From Ancient Times to the Present Day. (Cardiff: University of Wales Press).

Davis, Clarence and Kenneth E. Wilburn JR. and Ronald E. Robinson (1991) Railway Imperialism. (New York: Greenwood Press).

Davies, Glyn (2002) A History of Money: From Ancient Times to the Present Day. (Cardiff: University of Wales Press).

Debeir, Jean-Claude., Deléage, Jean-Paul, Hémery, Daniel, (1991) In the Servitude of Power: Energy and Civilization through the Ages. (London: Zed Books).

Dickson, P. G. M. (1967). The Financial Revolution in England: A Study in the Development of Public Credit 1688-1756 (London: Routledge).

Dimmock, Spencer (2014) The Origin of Capitalism in England, 1400-1600. (Leiden: Brill).

Di Muzio, Tim (2015) Carbon Capitalism: Energy, Social Reproduction and World Order. (London: Rowman Littlefield).

Di Muzio, Tim and Richard Robbins (2016) Debt as Power. (Manchester: Manchester University Press).

Dobb, Maurice (1946) Reprinted 1963. Studies in the Development of Capitalism. (London: Routledge and Kegan Paul).

Dutt, Romesh (1950) The Economic History of India in the Victorian Age. (London: Routledge and Kegan Paul).

Gill, Stephen (1995) 'Globalization, Market Civilization and Disciplinary Neoliberalism' Millennium: Journal of International Studies, Vol. 24, No. 3, 399-423.

Goody, Jack (2006) The Theft of History. (Cambridge UK, Cambridge University Press). 
Harman, Chris (2004) 'The Rise of Capitalism' International Socialism (2nd series), No.102, Spring: np. https:/www.marxists.org/archive/harman/2004/xx/risecap.htm (7/15/2015)

Harman, Chris and Robert Brenner (2006) 'The Origins of Capitalism' International Socialism (2nd series), No.111, Summer: np. https://www.marxists.org/archive/harman/2006/xx/wbrenner.htm (7/15/2015)

Heller, Henry (1985) 'The Transition Debate in Historical Perspective' Science \& Society Vol. 49, No. 2: 208-213.

Heller, Henry (2011) The Birth of Capitalism: A Twenty-first Century Perspective. (London: Pluto Press).

Hilton, Rodney (1976a) 'Feudalism and the Origins of Capitalism' History Workshop Journal, Vol. 1 Issue 1: 9-25.

Hilton, Rodney (ed) (1976b) Peasants, Knights and Heretics: Studies in Medieval English Social History. (Cambridge UK: Cambridge University Press).

Hobson, John A. (1902) Imperialism: A Study. https://www.marxists.org/archive/hobson/1902/imperialism/

Hobson, John M. (2004) The Eastern Origins of Western Civilization. (Cambridge UK: Cambridge University Press).

Horsefield, Keith, J. (1960) British Monetary Experiments, 1650-1710. (Cambridge, Mass: Harvard University Press).

Ingham, Geoffrey (2004) The Nature of Money. (Cambridge UK: Polity Press).

Johnston, Thomas (1934) The Financiers and the Nation. (London: Methuen \& Co. Ltd.)

Lefebvre, Georges et. al. (1982) The Transition from Feudalism to Capitalism. (London: Verso).

Losurdo, Domenico (2011) Liberalism: A Counter-History. (London: Verso). Tranlated by Gregory Elliott.

McNally, David (2014) 'The Blood of the Commonwealth' Historical Materialism Vol. 22 Issue 2: 3-32.

McNally, David (1988) Political Economy and the Rise of Capitalism: A Reinterpretation. (Berkeley: University of California Press).

Michie, Ranald (2001) The London Stock Exchange: A History. (Oxford UK: Oxford University Press).

Mielants, Eric H. (2007) The Origins of Capitalism and the Rise of the West. (Philadelphia: Temple University Press). 
Nitzan, Jonathan and Shimshon Bichler (2002) The Global Political Economy of Israel. (London: Pluto Press).

Nitzan, Jonathan and Shimshon Bichler (2009) Capital as Power: A Study of Order and Creorder. (London: Routledge).

Polanyi, Karl (1957) The Great Transformation: The Political and Economic Origins of our Times. (Boston: Beacon Press).

Shilliam, Robbie (2004) 'Hegemony and the Unfashionable Problematic of 'Primitive Accumulation’ Millennium: Journal of International Studies, Vol. 32, No. 1: 59-88.

Smil, Vaclav (1994) Energy is World History. (Boulder: Westview Press).

Smith, Adam (1776) An Inquiry into the Nature and Causes of the Wealth of Nations. The Electronic Classics Series, Jim Manis, Editor, PSU-Hazleton, Hazleton, PA.

Sweezy, Paul (1954) The Transition from Feudalism to Capitalism. (New York: Science and Society).

Tansel, Cemal Burak (2015) 'Deafening silence? Marxism, International Historical Sociology and the Spectre of Eurocentrism' European Journal of International Relations Vol. 21 Issue 1: 76-100.

Tawney, R.H. (1926) Religion and the Rise of Capitalism. (Harmondsworth: Penguin Books).

Thomas, Brinley (1993) The Industrial Revolution and the Atlantic Economy. (London: Routledge).

Thomas, Brinley (1986) 'Was There an Energy Crisis in Great Britain in the $17^{\text {th }}$ Century' Explorations in Economic History, Vol. 23: 124-152.

Vilar, Pierre (1984) A History of Gold and Money: 1450-1920. (London: Verso).

Wallerstein, Immanuel (1974) The Modern World System I: Capitalist Agriculture and the Origins of the European World-Economy in the Sixteenth Century. (New York: Academic Press).

Wennerlind, Carl (2011) Casualties of Credit: The English Financial Revolution, 1620-1720. (Cambridge, USA: Harvard University Press).

Williams, Michael (2006) Deforesting the Earth: From Prehistory to Global Crisis. (Chicago: University of Chicago Press).

Wolf, Eric R. (1982) Europe and the People Without History. (Berkeley: University of California Press).

Wood, Ellen Meiksins (2002) The Origin of Capitalism: A Longer View. (London: Verso).

Žmolek, Michael Andrew (2013) Rethinking the Industrial Revolution. (Leiden: Brill). 
URL: http:/mc.manuscriptcentral.com/gieh Email: criacis@hermes.cam.ac.uk 